\title{
PEA15 wt Allele
}

National Cancer Institute

\section{Source}

National Cancer Institute. PEA15 wt Allele. NCI Thesaurus. Code C79789.

Human PEA15 wild-type allele is located in the vicinity of 1q21.1 and is approximately 10 $\mathrm{kb}$ in length. This allele, which encodes astrocytic phosphoprotein PEA-15 protein, may be involved in the modulation of signaling, transport of carbohydrates and protein localization. Aberrant gene expression is associated with type 2 diabetes and ovarian cancer. 